license

\title{
Penguatan Kapasitas Kelembagaan Program Kota Layak Anak dalam \\ Penanganan Permasalahan Kekerasan Seksual Anak di Kota Surakarta
}

Cintia Cahya Ningrum ${ }^{1}$, Sri Yuliani ${ }^{2}$

cahyacintia12@gmail.com; sriyuliani63@staff.uns.ac.id

${ }_{1}^{1}$ Program Studi Ilmu Administrasi Negara, Universitas Negeri Surakarta

2 Program Studi Ilmu Administrasi Negara, Universitas Negeri Surakarta

DOI: $10.22219 /$ sospol.v7i2.10839

\begin{abstract}
This research focuses on explaining how steps must be taken to strengthen the
Child Friendly City Policy program as an effort to handle child sexual violence in Surakarta City. Child Friendly City itself is a form of Child Protection Policy that was made in 2006, where the City of Surakarta became one of the pilot projects in this program. In 2017 Surakarta City has received an award for the Main Category, but cases such as Child Sexual Violence (KSA) tend to increase every year. In the Child Friendly City program, there are indicators for Institutional Strengthening and 5 Cluster indicators for Children's Rights that must be met. The Special Protection Indicator is one of the indicators that has a lower rating than the other 4 indicators. By using a qualitative descriptive method, this study found that in order to maximize the strengthening of the Child Friendly City program in dealing with the problem of sexual violence against children, it is necessary to strengthen institutional capacity, especially in cluster 5. Children, budget consistency, Dinas participation in certified KHA training, and holding regular coordination meetings between stakeholders involved.
\end{abstract}

\begin{abstract}
Abstrak
Penelitian ini berfokus menjelaskan bagaimana langkah yang mesti dilakukan dalam penguatan program Kebijakan Kota Layak Anak sebagai upaya penanganan kekerasan seksual anak di Kota Surakarta. Kota Layak Anak sendiri merupakan salah satu bentuk Kebijakan Perlindungan Anak yang dibuat pada tahun 2006, dimana Kota Surakarta menjadi salah satu pilot project dalam program ini. Pada tahun 2017 Kota Surakarta telah mendapatkan penghargaan untuk Kategori Utama, namun kasus seperti Kekerasan Seksual Anak (KSA) cenderung mengalami peningkatan tiap tahunnya. Dalam program Kota Layak Anak terdapat indikator Penguatan Kelembagaan dan 5 indikator Klaster Hak Anak yang harus dipenuhi. Indikator Perlindungan Khusus menjadi salah satu indikator yang memiliki penilaian lebih rendah dibanding ke-4 indikator lainnya. Dengan menggunakan menggunakan metode deskriptif kualitatif, penelitian ini menghasilkan temuan bahwa guna memaksimalkan penguatan program Kota Layak Anak dalam menangani masalah kekerasan seksual terhadap anak diperlukan adanya pembaharuan Peraturan Daerah Kota Surakarta tentang Perlindungan Anak, adanya konsistensi anggaran, keikutsertaan Dinas dalam pelatihan KHA bersertifikat, serta diadakannya rapat koordinasi rutin antar stakeholder yang terlibat.
\end{abstract}

\author{
Keywords \\ Kapasitas Kelembagaan, Kekerasan \\ Seksual Anak, Kota Layak, Anak, \\ Surakarta
}

\section{Article History}

Received February 27, 2020

Revised June 16, 2020

Accepted November 10, 2021

Published November 17, 2021

\section{Corresponding Author}

Cintia Cahya Ningrum.

Program Studi Ilmu

Administrasi Negara, Universitas Sebelas Maret, Jl. Ir. Sutami No.36 A, Pucangsawit, Jebres, Surakarta, Indonesia. 57126. 
license

\section{Pendahuluan}

Perlindungan anak telah menjadi perhatian dan komitmen global sejak disahkannya Konvensi Hak-hak Anak. Namun data dari WHO tahun 2017 menunjukkan bahwa setengah dari dua juta anak-anak di dunia menjadi korban kekerasan fisik, seksual atau emosional atau penelantaran (www.voaindonesia.com, 2018). Kondisi anak di Indonesia pun tidak jauh berbeda dengan kondisi global, dimana tingkat kekerasan seksual cukup tinggi. Catatan tahunan yang dibuat oleh Komnas Perempuan 2018 menunjukan sekitar 31\% dari 2.227 kasus adalah kasus kekerasan seksual (Komisi Nasional Anti Kekerasan Terhadap Perempuan, 2018). Padahal di Indonesia, jumlah anak-anak mencapai 33\% dari total populasi penduduk atau sekitar 83 juta jiwa.

Sebagai respon atas potensi semakin tingginya kekerasan seksual terhadap anak, pemerintah Indonesia, melalui Kementerian Pemberdayaan Perempuan dan Perlindungan Anak (KEMENPPPA), menetapkan Kebijakan Perlindungan Anak yang kemudian diikuti dengan perilisan Program Kabupaten/Kota Layak Anak (KLA). Berdasarkan pada Bahan Advokasi Kebijakan KLA yang disusun oleh Deputi Tumbuh Kembang Anak KEMENPPPA RI, dijelaskan bahwa Kabupaten/Kota Layak Anak ialah Kabupaten/Kota yang mempunyai sistem pembangunan berbasis hak anak melalui pengintegrasian komitmen dan sumber daya pemerintah, masyarakat dan dunia usaha, yang terencana secara menyeluruh dan berkelanjutan dalam kebijakan, program dan kegiatan untuk menjamin pemenuhan hak dan perlindungan anak (Rosalina, et al., 2017).

KLA di Indonesia pertama kali diuji cobakan pada tahun 2006 dan Kota Surakarta menjadi salah satu pilot project pada program ini. Sudah lebih dari satu dekade Kota Surakarta merilis KLA, namun baru ditahun 2017 Kota Surakarta mendapat penghargaan Kategori Utama. Meski telah mendapat penghargaan tersebut namun realita di lapangan masih banyak terjadi permasalahan yang dihadapi oleh anak. Catatan dari Dinas Sosial Kota Surakarta menyebutkan bahwa terdapat 77 laporan terkait kasus anak, dimana kasus Kekerasan Seksual Anak (KSA) menjadi yang paling banyak dilaporkan. Guna menjadi sebuah Kota dengan predikat KLA terdapat beberapa indikator yang mesti dipenuhi, yaitu : 1) Hak Sipil dan Kebebasan; 2) Lingkungan Keluarga dan Pengasuhan Alternatif; 3) Kesehatan Dasar dan Kesejahteraan; 4) Pendidikan, Pemanfaatan Waktu Luang dan Kegiatan Budaya; 5) Perlindungan Khusus. Selain itu terdapat satu tambahan indikator lagi yaitu Penguatan Kelembagaan. Berdasarkan evaluasi KLA di Kota Surakarta dari KEMENPPPA, terdapat 2 indikator yang memiliki penilaian lebih rendah, salah satunya adalah indikator Perlindungan Khusus. Kekerasan Seksual Anak (KSA) sendiri merupakan bagian dari Anak yang memerlukan Perlindungan Khusus (AMPK).

Pencapaian Kota Surakarta dalam mewujudkan KLA tidak terlepas dari kinerja Dinas Pemberdayaan Perempuan, Perlindungan Anak, dan Pemberdayaan Masyararakat (DP3APM) sebagai leading sector. Berbagai riset terdahulu banyak yang telah membahas mengenai upaya mewujudkan KLA. Salah satu yang terbaru ialah riset dari Hamudy (2015) yang mengasilkan temuan berupa adanya puskesmas ramah anak yang dilakukan oleh pemerintah Kota Surakarta dan Makassar sebagai salah satu cara mewujudkan KLA. Selain itu terdapat pula riset dari Fithriyyah (2017) yang menyoroti kurang optimalnya penerapan KLA di Kota Pekanbaru. Berdasarkan paparan diatas, tulisan ini akan berfokus untuk menganalisa bagaimana penguatan kapasitas kelembagaan KLA untuk menangani permasalahan KSA di Kota Surakarta ini seharusnya dilakukan. 
Guna menjawab pertanyaan diatas, tulisan ini akan menggunakan Penguatan Kapasitas Kelembagaan sebagai kerangka berpikir. Menurut Grindle (1997:6) dalam (Kesumaningrum, 2016) penguatan kapasitas kelembagaan sebagai upaya untuk menunjang performa institusi menjadi lebih efisien, efektif, dan responsive. Penguatan kapasitas berarti terjadi perubahan perilaku untuk meningkatkan kemampuan individu dalam pengetahuan, ketrampilan dan sikap; meningkatkan kemampuan kelembagaan dalam organisasi dan manajemen, keuangan dan budaya; serta meningkatkan kemampuan masyarakat dalam kemandirian, kewaspadaan dan mengantisipasi perubahan.

Berdasarkan Peraturan Menteri Negara Pemberdayaan Perempuan dan Perlindungan Anak Republik Indonesia Nomor 12 Tahun 2011 tentang indikator KLA, penguatan kapasitas kelembagaan memiliki 7 sub-indikator, namun dalam penelitian ini hanya akan membahas 4 subindikator yaitu : 1) adanya peraturan perundang-undangan dan kebijakan untuk pemenuhan hak anak; 2) presentase anggaran untuk pemenuhan hak anak, termasuk anggaran untuk penguatan kelembagaan; 3) tersedia SDM terlatih KHA dan mampu menerapkan hak anak ke dalam kebijakan, program dan kegiatan; 4) keterlibatan LSM dalam pemenuhan hak anak. Ke-4 subindikator inilah yang akan dianalisis karena sesuai dengan Teori Sumpeno tentang penguatan Kapasitas.

\section{Metode Penelitian}

Penelitian ini merupakan penelitian deskriptif kualitatif menurut Lexy J. Moloeng (2004) dalam (Agustinova, 2015). Hal ini dikarenakan penelitian ini bertujuan untuk menganalisadan mendeskripsikan tentang penguatan kapasitas kelembagaan program KLA dalam menangani permasalahan KSA. Teknik penentuan informan dalam penelitian ini menggunakan teknik Purposive Sampling (Sarwono, 2006). Data yang digunakan dalam penelitian ini adalah data primer dan sekunder (Sarwono, 2006). Data primer berupa hasil wawancara dengan Kepala Bidang PA DP3APM, Kepala UPT PTPAS, dan Ketua Program Yayasan KAKAK. Sedangkan data sekunder berasal dari dokumen berupa Undang-Undang, Peraturan Menteri, Peraturan Walikota maupun Peraturan Daerah. Dalam menguji keabsahan data penelitian ini menggunakan metode triangulasi sumber dan metode (Moleong, 2010). Teknik analisis data yang digunakan dalam penelitian ini menggunakan Analisis Data Miles dan Hubermen (1984) dalam (Agustinova, 2015).

\section{Hasil dan Pembahasan}

Kota Surakarta sudah menerapkan program KLA lebih dari satu dasawarsa dan mendapat penghargaan Kategori Utama. Namun dalam evaluasi yang dilakukan oleh KEMENPPPA, penilaian untuk klaster 5 menjadi salah satu penilaian yang lebih rendah dibanding ke-4 indikator lainnya. Oleh sebab itu, penelitian ini akan membahas mengenai Penguatan Kelembagaan KLA untuk klaster 5 terkhusus dalam menangani permasalahan KSA di Kota Surakarta.

\section{Peraturan Perundang-undangan dan Kebijakan tentang KSA}

Komitmen kuat Pemerintah Kota Surakarta untuk mewujudkan KLA dapat terlihat dari berbagai Kebijakan maupun Regulasi Daerah, berikut identifikasinya 
Tabel 1. Identifikasi Peraturan Perundang-undangan dan Kebijakan yang Mengatur tentang Kekerasan Seksual Anak (KSA)

\begin{tabular}{|c|c|}
\hline $\begin{array}{l}\text { Nama Undang- } \\
\text { Undang }\end{array}$ & Pelindungan Khusus \\
\hline $\begin{array}{l}\text { Undang-Undang } \\
\text { Nomor } 35 \text { Tahun } \\
2014 \text { tentang } \\
\text { Perubahan atas } \\
\text { Undang-Undang } \\
\text { Nomor } 23 \text { Tahun } \\
2002 \text { tentang } \\
\text { Perlindungan Anak }\end{array}$ & $\begin{array}{l}\text { Perlindungan Khusus adalah suatu bentuk perlindungan } \\
\text { yang diterima oleh Anak dalam situasi dan kondisi } \\
\text { tertentu untuk mendapatkan jaminan rasa aman } \\
\text { terhadap ancaman yang membahayakan diri dan jiwa } \\
\text { dalam tumbuh kembangnya (Pasal } 1 \text { ayat 15). } \\
\text { Kekerasan adalah setiap perbuatan terhadap Anak yang } \\
\text { berakibat timbulnya kesengsaraan atau penderitaan } \\
\text { secara fisik, psikis, seksual, dan/atau penelantaran, } \\
\text { termasuk ancaman untuk melakukan perbuatan, } \\
\text { pemaksaan, atau perampasan kemerdekaan secara melawan } \\
\text { hukum (Pasal } 1 \text { ayat 15a). } \\
\text { Setiap Anak berhak untuk memperoleh perlindungan dari: } \\
\text { a. penyalahgunaan dalam kegiatan politik; } \\
\text { b. pelibatan dalam sengketa bersenjata; } \\
\text { c. pelibatan dalam kerusuhan sosial; } \\
\text { d.pelibatan dalam peristiwa yang mengandung unsur } \\
\text { Kekerasan; } \\
\text { e. pelibatan dalam peperangan; dan } \\
\text { f. kejahatan seksual (Pasal 15). } \\
\text { Untuk menjamin pemenuhan Hak Anak dan melaksanakan } \\
\text { kebijakan di bidang penyelenggaraan Perlindungan Anak, } \\
\text { Pemerintah Daerah berkewajiban dan bertanggung } \\
\text { jawab untuk melaksanakan dan mendukung } \\
\text { kebijakan nasional dalam penyelenggaraan } \\
\text { Perlindungan Anak di daerah. Kebijakan tersebut dapat } \\
\text { diwujudkan melalui upaya daerah membangun } \\
\text { kabupaten/kota layak Anak (Pasal } 21 \text { ayat } 4 \text { dan 5). } \\
\text { Pemerintah, Pemerintah Daerah, dan lembaga negara } \\
\text { lainnya berkewajiban dan bertanggung jawab untuk } \\
\text { memberikan Perlindungan Khusus kepada: } \\
\text { a. Anak dalam situasi darurat; } \\
\text { b. Anak yang berhadapan dengan hukum; } \\
\text { c. Anak dari kelompok minoritas dan terisolasi; } \\
\text { dan/atau seksual; }\end{array}$ \\
\hline
\end{tabular}


e. Anak yang menjadi korban penyalahgunaan narkotika, alkohol, psikotropika, dan zat adiktif lainnya;

\section{f. Anak yang menjadi korban pornografi;}

g. Anak dengan HIV/AIDS;

h. Anak korban penculikan, penjualan, dan/atau perdagangan;

i. Anak korban Kekerasan fisik dan/atau psikis;

j. Anak korban kejahatan seksual;

$\mathrm{k}$. Anak korban jaringan terorisme;

1. Anak Penyandang Disabilitas;

m. Anak korban perlakuan salah dan penelantaran;

n. Anak dengan perilaku sosial menyimpang; dan

o. Anak yang menjadi korban stigmatisasi dari pelabelan terkait dengan kondisi Orang Tuanya (Pasal 59 ayat 1 $\& 2)$.

Perlindungan Khusus bagi Anak sebagaimana dilakukan melalui upaya :

a. penanganan yang cepat, termasuk pengobatan dan/atau rehabilitasi secara fisik, psikis, dan sosial, serta pencegahan penyakit dan gangguan kesehatan lainnya;

b. pendampingan psikososial pada saat pengobatan sampai pemulihan;

c. pemberian bantuan sosial bagi Anak yang berasal dari Keluarga tidak mampu; dan

d. pemberian perlindungan dan pendampingan pada setiap proses peradilan (Pasal 59A).

Perlindungan Khusus bagi Anak yang dieksploitasi secara ekonomi dan/atau seksual dilakukan melalui :

a. penyebarluasan dan/atau sosialisasi ketentuan peraturan perundang-undangan yang berkaitan dengan Perlindungan Anak yang dieksploitasi secara ekonomi dan/atau seksual;

b. pemantauan, pelaporan, dan pemberian sanksi; dan

c. pelibatan berbagai perusahaan, serikat pekerja, lembaga swadaya masyarakat, dan Masyarakat dalam penghapusan eksploitasi terhadap Anak secara ekonomi dan/atau seksual (Pasal 66).

Perlindungan Khusus bagi Anak korban kejahatan seksual dilakukan melalui upaya : 
a. edukasi tentang kesehatan reproduksi, nilai agama, dan nilai kesusilaan;

b. rehabilitasi sosial;

c. pendampingan psikososial pada saat pengobatan sampai pemulihan; dan

d. pemberian perlindungan dan pendampingan pada setiap tingkat pemeriksaan mulai dari penyidikan, penuntutan, sampai dengan pemeriksaan di sidang pengadilan (Pasal 69A).

Setiap Orang dilarang melakukan Kekerasan atau ancaman Kekerasan memaksa Anak melakukan persetubuhan dengannya atau dengan orang lain (Pasal 76D).

Setiap Orang dilarang melakukan Kekerasan atau ancaman Kekerasan, memaksa, melakukan tipu muslihat, melakukan serangkaian kebohongan, atau membujuk Anak untuk melakukan atau membiarkan dilakukan perbuatan cabul (Pasal 76E).

Setiap Orang dilarang menempatkan, membiarkan, melakukan, menyuruh melakukan, atau turut serta melakukan eksploitasi secara ekonomi dan/atau seksual terhadap Anak (Pasal 76I).

Setiap orang yang melangggar ketentuan sebagaimana dimaksud dalam Pasal 76D dipidana dengan pidana penjara paling singkat 5 (lima) tahun dan paling lama 15 (lima belas) tahun dan denda paling banyak Rp5.000.000.000,00 (lima miliar rupiah). Ketentuan pidana tersebut berlaku pula bagi Setiap Orang yang dengan sengaja melakukan tipu muslihat, serangkaian kebohongan, atau membujuk Anak melakukan persetubuhan dengannya atau dengan orang lain. Apabila tindak pidana tersebut dilakukan oleh Orang Tua, Wali, pengasuh Anak, pendidik, atau tenaga kependidikan, maka pidananya ditambah $1 / 3$ (sepertiga) dari ancaman pidana yang telah ditetapkan tersebut (Pasal 81).

Setiap orang yang melanggar ketentuan sebagaimana dimaksud dalam Pasal 76E dipidana dengan pidana penjara paling singkat 5 (lima) tahun dan paling lama 15 (lima belas) tahun dan denda paling banyak Rp5.000.000.000,00 (lima miliar rupiah). Apabila tindak pidana tersebut dilakukan oleh Orang Tua, Wali, 


\begin{tabular}{|c|c|}
\hline & $\begin{array}{l}\text { pengasuh Anak, pendidik, atau tenaga kependidikan, } \\
\text { maka pidananya ditambah } 1 / 3 \text { (sepertiga) dari } \\
\text { ancaman pidana tersebut (Pasal 82). } \\
\text { Setiap Orang yang melanggar ketentuan sebagaimana } \\
\text { dimaksud dalam Pasal 76I, dipidana dengan pidana } \\
\text { penjara paling lama } 10 \text { (sepuluh) tahun dan/atau } \\
\text { denda paling banyak Rp200.000.000,00 (dua ratus juta } \\
\text { rupiah) (Pasal 88). }\end{array}$ \\
\hline $\begin{array}{l}\text { Peraturan Daerah } \\
\text { Kota Surakarta } \\
\text { Nomor } 4 \text { Tahun } \\
2012 \text { tentang } \\
\text { Perlindungan Anak }\end{array}$ & $\begin{array}{l}\text { Perlindungan anak adalah segala kegiatan untuk } \\
\text { menjamin dan melindungi anak dan hak-haknya agar } \\
\text { dapat hidup tumbuh, berkembang, dan berpartisipasi, } \\
\text { secara optimal sesuai dengan harkat dan martabat } \\
\text { kemanusiaan, serta mendapat perlindungan dari } \\
\text { kekerasan, eksploitasi, penelantaran dan perlakukan } \\
\text { salah (Pasal } 1 \text { ayat 10). } \\
\text { Perlindungan khusus adalah perlindungan yang diberikan } \\
\text { kepada anak korban kekerasan, eksploitasi, penelantaran } \\
\text { dan perlakuan salah, yaitu: } \\
\text { a. anak dalam situasi darurat; } \\
\text { b. anak yang berhadapan dengan hukum (ABH); } \\
\text { c. anak tereksploitasi secara ekonomi dan/atau seksual; } \\
\text { d. anak yang menjadi korban penyalahgunaan narkotika, } \\
\text { alkohol, psikotropika, dan zat adiktif lainnya (napza); } \\
\text { e. anak korban penculikan, penjualan dan perdagangan; } \\
\text { f. anak korban kekerasan baik fisik dan atau mental, anak } \\
\quad \text { difabel; } \\
\text { g. anak korban perlakuan salah dan penelantaran; } \\
\text { h. anak yang diperdagangkan; dan } \\
\text { i. pekerja anak (Pasal } 1 \text { ayat } 11 \text { \& } 12 \text { ). } \\
\text { Anak yang tereksploitasi seksual adalah anak yang } \\
\text { digunakan atau dimanfaatkan untuk tujuan seksualitas } \\
\text { dengan imbalan tunai atau dalam bentuk lain antar } \\
\text { anak, pembeli jasa seks, perantara atau agen dan pihak lain } \\
\text { yang memperoleh keuntungan dari perdagangan seksualitas } \\
\text { anak tersebut (Pasal } 1 \text { ayat } 18 \text { ). } \\
\text { Pemerintah daerah dan lembaga lainnya berkewajiban dan } \\
\text { bertanggung jawab untuk memberikan perlindungan } \\
\text { khusus, yang meliputi: } \\
\text { a. anak dalam situasi darurat; } \\
\text { b. anak yang berhadapan dengan hukum (ABH); }\end{array}$ \\
\hline
\end{tabular}




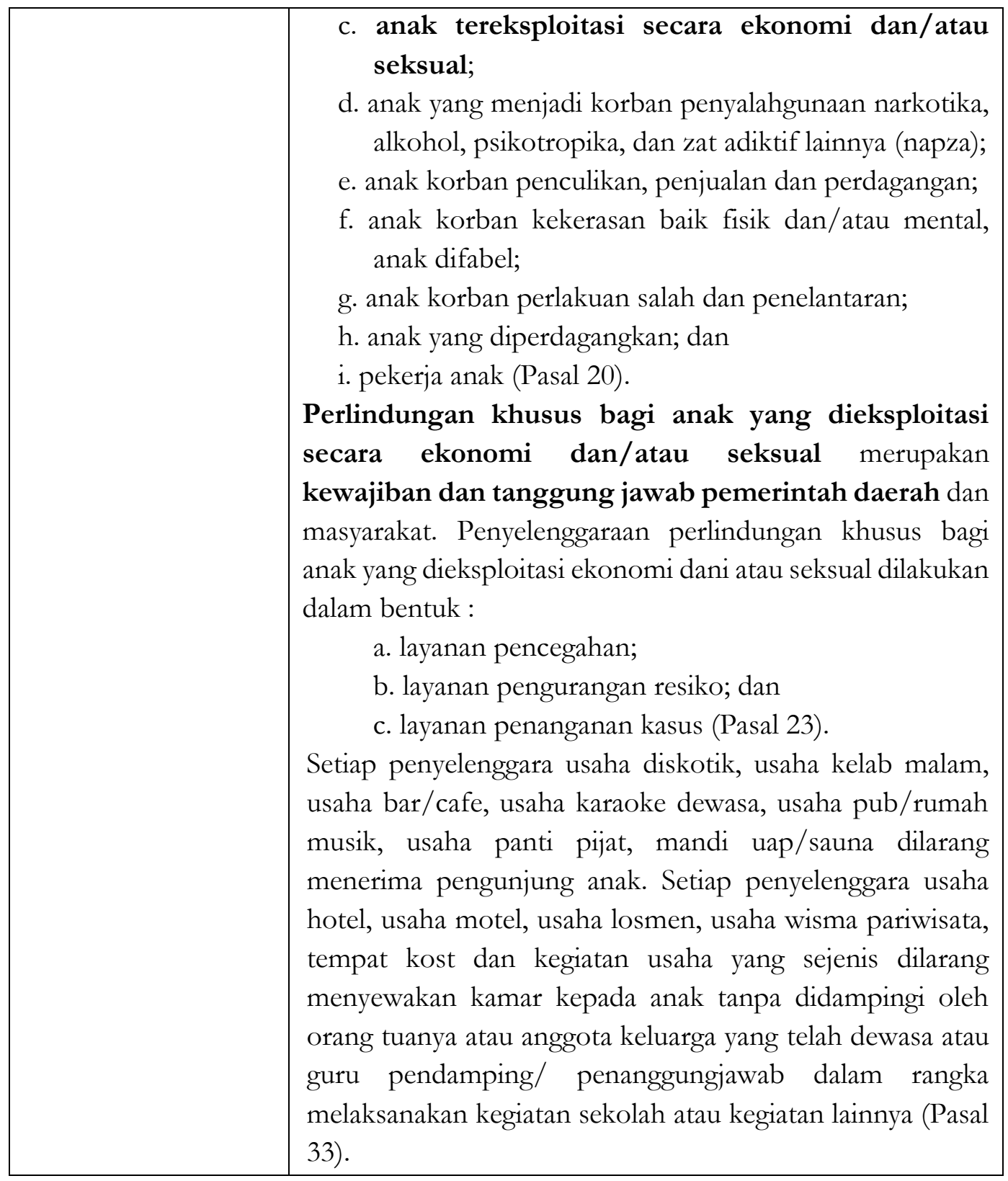




\begin{tabular}{|c|c|}
\hline $\begin{array}{l}\text { Peraturan Daerah } \\
\text { Kota Surakarta } \\
\text { Nomor } 3 \text { Tahun } \\
2006 \text { tentang } \\
\text { Penanggulangan } \\
\text { Eksploitasi Seksual } \\
\text { Komersial }\end{array}$ & $\begin{array}{l}\text { Prostitusi adalah penggunaan orang dalam kegiatan } \\
\text { seksual dengan pembayaran atau dengan imbalan dalam } \\
\text { bentuk lain. } \\
\text { Eksploitasi adalah tindakan pemanfaatan fisik, seksual, } \\
\text { tenaga dan/atau kemampuan diri sendiri oleh pihak lain } \\
\text { yang dilakukan atau sekurang-kurangnya dengan cara } \\
\text { sewenang-wenang atau penipuan yang dilakukan untuk } \\
\text { mendapatkan keuntungan baik material maupun non } \\
\text { material. } \\
\text { Seksual Komersial adalah segala tindakan } \\
\text { mempergunakan badan/fisik untuk kepuasan seksual orang } \\
\text { lain dengan imbalan tunai atau dalam bentuk lain. } \\
\text { Eksploitasi Seksual Komersial adalah tindakan } \\
\text { eksploitasi terhadap orang (dewasa dan anak, perempuan } \\
\text { dan laki-laki) untuk tujuan seksual dengan imbalan tunai } \\
\text { atau dalam bentuk lain antara orang, pembeli jasa seks, } \\
\text { perantara atau agen, dan pihak lain yang memperoleh } \\
\text { keuntungan dari perdagangan seksualitas orang tersebut. } \\
\text { (Pasal } 1 \text { ayat 20, 21, 22, \& 23). } \\
\text { Setiap orang dilarang melakukan kegiatan prostitusi } \\
\text { anak, baik dengan pasangan sejenis dan/atau lawan jenis } \\
\text { (Pasal } 4 \text { ayat 2). }\end{array}$ \\
\hline
\end{tabular}

Sumber : diolah dari dokumen Undang-Undang dan regulasi Kota Surakarta.

Berdasarkan tabel diatas terlihat bahwa Peraturan Daerah Surakarta Nomor 4 Tahun 2012 tentang Perlindungan Anak masih mengacu pada Undang-Undnag Nomor 23 Taahun 2002 tentang Perlindungan Anak yang lama. Meskipun Kota Surakarta pun memiliki Perda tentang Penanggulangan Eksploitasi Seksual Komersial sendiri, namun masih ada beberapa penjelasan maupun definisi yang kurang lengkap dan kurang terperinci, hal ini juga berdampak pada bagaimana penanggulangan itu dilakukan, larangan maupun hukuman dari tindak pidana itu ditentukan.

\section{Anggaran untuk penanganan KSA dan Penguatan Kelembagaan}

Dalam mewujudkan Kota Surakarta sebagai KLA tentunya tidak hanya sekedar peraturan maupun perundang-undangan yang diperlukan. Anggaran menjadi salah satu hal yang krusial dalam pelaksanaan setiap program. Tentunya jika Pemerintah berkomitmen kuat dalam mewujudkan KLA maka sudah seharusnya Pemerintah Kota juga berkomitmen dalam mengalokasikan anggaran. Di Kota Surakarta, untuk penanganan klaster 5 sepenuhnya berada pada UPT PTPAS. Sedangkan untuk penguatan kelembagaan KLA sendiri menginduk pada kelima klaster tersebut. Berikut penjabaran mengenai alokasi anggaran klaster 5 yang ada pada UPT PTPAS : 
Tabel 4. Anggaran UPT PTPAS

\begin{tabular}{|c|c|c|c|}
\hline Tahun & Uraian Penggunaan Anggaran & Jumlah (Rp) & $\begin{array}{c}\text { Total Penggunaan } \\
\text { Anggaran (Rp) }\end{array}$ \\
\hline \multirow[t]{3}{*}{2017} & Program Pelayanan Administrasi & 119.620 .000 & \multirow[t]{3}{*}{504.620 .000} \\
\hline & $\begin{array}{l}\text { Program Penguatan Kelembagaan } \\
\text { Pengarusutamaan Gender \& Anak }\end{array}$ & 225.000 .000 & \\
\hline & $\begin{array}{l}\text { Program Peningkatan Kualitas Hidup \& } \\
\text { Perlindungan Perempuan }\end{array}$ & 160.000 .000 & \\
\hline \multirow[t]{3}{*}{2018} & Program Pelayanan Administrasi & 128.225 .000 & \multirow[t]{3}{*}{855.031 .000} \\
\hline & $\begin{array}{l}\text { Program Penguatan Kelembagaan } \\
\text { Pengarusutamaan Gender \& Anak }\end{array}$ & 394.699 .200 & \\
\hline & $\begin{array}{l}\text { Program Peningkatan Kualitas Hidup \& } \\
\text { Perlindungan Perempuan }\end{array}$ & 332.106 .800 & \\
\hline \multirow[t]{3}{*}{2019} & Program Pelayanan Administrasi & 102.731 .000 & \multirow[t]{3}{*}{513.570 .000} \\
\hline & $\begin{array}{l}\text { Program Penguatan Kelembagaan } \\
\text { Pengarusutamaan Gender \& Anak }\end{array}$ & 208.199.000 & \\
\hline & $\begin{array}{l}\text { Program Peningkatan Kualitas Hidup \& } \\
\text { Perlindungan Perempuan }\end{array}$ & 202.640 .000 & \\
\hline
\end{tabular}

Sumber : diolah dari Anggaran UPT PTPAS selama 2017-2019

Dari tabel tersebut tidak terlalu terlihat, berapa alokasi anggaran sebenarnya untuk klaster 5, tetapi lebih kepada anggaran di UPT PTPAS secara umum seperti anggaran untuk Pelayanan Administrasi Perkantoran. Meskipun juga terdapat anggaran untuk Program Penguatan Kelembagaan Pengarusutamaan Gender dan Anak, serta anggaran untuk Program Peningkatan Kualitas Hidup dan Perlindungan Perempuan namun tidak terlalu banyak kegiatan yang terinci didalamnya. Untuk Program Penguatan Kelembagan Pengarusutamaan Gender dan Anak, uraian dari program tersebut adalah untuk Fasilitas Pengembangan Pusat Pelayanan Terpadu Pemberdayaan Perempuan (P2TP2), Sedangkan uraian dari Program Peningkatan Kualitas Hidup dan Perlindungan Perempuan adalah Penyusunan Sistem Perlindungan bagi Perempuan, dan Sosialisasi Sistem Pencatatan dan Pelaporan KDRT.

Namun, karena anggaran tersebut merupakan anggaran keseluruhan untuk klaster 5, maka anggaran untuk penanganan KSA juga termasuk didalamnya. Dari penjabaran diatas dapat terlihat bahwa anggaran untuk klaster 5 fluktuatif. Peningkatan anggaran secara signifikan terjadi tahun 2018. Di tahun 2019 kemudian terjadi penurunan atau hampir sama dengan anggaran ditahun 2017. Untuk anggaran penguatan kelembagaan pun juga fluktuatif, Dari sini terlihat bahwa komitmen Pemerintah Kota Surakarta belum terlalu terlihat dalam bentuk penguatan anggaran. Karena menurut teori Penguatan Kapasitas Kelembagaan, seharusnya terjadi peningkatan kemampuan kelembagaan dalam organisasi manajemen, keuangan, dan budaya. 
license

\section{Peningkatan Kualitas Sumber Daya Manusia}

Terwujudnya Surakarta sebagai Kota Layak Anak juga tidak bisa terlepas dari Sumber Daya Manusia yang terlatih akan KHA. Pelatihan yang dimaksud adalah yang memenuhi standar materi, pendalaman masalah dan penanganan isu anak berdasarkan KHA. Bidang Perlindungan Anak (PA) sendiri terdiri dari 8 (delapan) orang, dari kedelapan anggota bidang PA tersebut, terdapat 3 (tiga) orang yang belum mengikuti pelatihan KHA. Dikarenakan selain non-ASN, mereka memiliki tupoksi yang berbeda, yaitu 2 (dua) orang Puspaga dan 1 (satu) orang Administrator. Selain itu ternyata mereka mengikuti Pelatihan KHA yang diadakaan oleh Provinsi namun tidak mendapat sertifikat, sehingga hal ini berpengaruh terhadap evaluasi penilaian KHA. Dalam hal ini, Bidang PA seharusnya mengikuti pelatihan yang mendapat sertifikat, terlebih lagi apabila pelatihan yang dilakukan juga melatih skill atau keterampilan. Penguatan kapasitas berarti meningkatkan kemampuan individu tidak hanya dalam pengetahuan tetapi juga dalam hal keterampilan dan sikap.

Bidang PA DP3APM sendiri juga membuat pelatihan untuk tenaga pendidik, tenaga kesehatan, pekerja sosial, aparat penegak hukum, dsb. Pelatihan KHA ini memang diperlukan karena ini hal mendasar mengenai Hak Anak.Melalui pelatihan yang dibuat, dihaarapkan petugas pemberi layanan mampu melayani dan mendampingi anak dengan memperhatikan kepentingan terbaik bagi anak, tidak diskriminatif, dan memperhatikan pendapat anak. Pelatihan KHA dilaksanakan tiap tahunnya, peserta Pelatihan KHA pun harus berbeda tiap tahunnya, apabila Lembaga atau Dinas sudah pernah mengikuti pelatihan sebelumnya, maka peserta yang dikirimkan haruslah berbeda atau belum pernah mengikuti pelatihan sebelumnya. Pelatihan tersebut dilakukan supaya tersedianya SDM terlatih KHA serta mampu menerapakan Hak Anak ke dalam kebijakan, program dan kegiatan.

\section{Kesimpulan}

Berdasarkan paparan diatas, dapat disimpulkan bahwa terdapat beberapa langkah yang perlu dilakukan oleh pemerintah Kota Surakarta dalam upaya Penguatan Kapasitas Kelembagaan Program KLA, terutama berkaitan dengan Penanganan Permasalahan KSA di Kota Surakarta. Pertama, dari segi Peraturan Perundang-undangan maupun Kebijakan, Kota Surakarta perlu melakukan pembaharuan Peraturan Daerah Kota Surakarta tentang Perlindungan Anak mengacu pada Undang-Undang Perlindungan Anak terbaru yaitu UU Nomor 35 Tahun 2014 tentang Perlindungan Anak. Ketiga, dalam hal anggaran masih perlu adanya konsistensi anggaran sehingga anggaran yang digunakan tidak melonjak terlalu tinggi maupun menurun terlalu banyak. Ketiga SDM dalam bidang PA di DP3APM perlu mengikuti pelatihan KHA yang memberikan sertifikat, sehingga dengan begitu dapat memberi dampak positif pada penilaian evaluasi KLA mendatang. Perlu adanya rapat koordinasi rutin antara UPT PTPAS dengan lembaga-lembaga terkait lainnya sehingga penyelesaian masalah menjadi lebih cepat.

\section{Referensi}

Abdillah, U. (2002). Politik Identitas Etnis : Pergulatan Tanda Tanpa Identitas. Magelang: Indonesia Tera.

Ambardi, K. (2009). Mengungkap Politik Kartel: Studi Tentang Sistem Kepartaian di Indonesia Era Reformasi. Jakarta: Gramedia \& LSI. 
Buchari, S., R. (2014). Kebangkitan etnis menuju politik identitas. Jakarta: Yayasan Pustaka Obor Indonesia.

Chandakirana, K. (1989). Geertz dan Masalah Kesukuan. Jakarta. Prisma No. 2/1989.

Cnnindonesia.com. (2019). Polisi Sebut 33 Korban Tewas Di Wamena Akibat Kerusuhan. Online. Diakses dari https://www.cnnindonesia.com/ nasional/20191028204602-20443648/polisisebut-33-korban-tewas-di-wamena-akibat-kerusuhan

Fukuyama, F. (2018). Identity: The Demand for Dignity and the Politics of Resentment. New York: Farrar, Straus, and Giroux

Geertz, Clifford. (1963). The Integrative Rovolution: Primordial Sentiments and Civil Politics in The New States. New York: Free Press.

Geertz, Clifford. (1983). Abangan, Santri, Priyayi Dalam Masyarakat Jawa. Jakarta: Dunia Pustaka Jaya.

Hamid, A. (2019) Populism In The 2017 Jakarta Gubernatorial Election. Journal of Governance, Vol 4, No 1

Jumadi. (2003). Fenomena Etnis Dalam Proses Rekruitmen Elit Politik Lokal: Kasus Pemilihan Bupati dan Wakil Bupati Kabupaten Ketapang Kalbar 2000-2005. Yogyakarta. Tesis UGM.

Morowitz. D., L. (1998). Demokrasi Pada Masyarakat Majemuk. Dalam Larry Diamond dan Mars F Plattner. Nasionalisme, Konflik Etnik dan Demokrasi Bandung. ITB Pres

Habbodin, M. (2012). Menguatnya Politik Identitas Di Ranah Lokal. Jurnal Studi Pemerintahan, Vol 3 , No 1.

Haryanto. (2009). Elit Politik Lokal dalam Perubahan Sistem Politik. Jurnal Sosial Politik, Vol 13, No 2.

Huntington, S.,P. (2007). Benturan Antarperadaban dan Masa Depan Politik Dunia (terj.). Yogyakarta: Qalam

Lee, H. (2009). Furnivall's Plural Society and Leach's Political Systems of Highland Burma. Sojourn: Journal of Social Issues in Southeast Asia,24(1), 32-46. Retrieved from www.jstor.org/stable/41308110

Levistky, S \& Ziblat, D. (2018). Bagaimana Demokasi Mati. Jakarta: Gramedia Pustaka Utama

Mietzner, M. (2008). Comparing Indonesia's party systems of the 1950s and the post-Suharto era: From centrifugal to centripetal inter-party competition. Journal of Southeast Asian Studies, 39(3), pp 431-453 October 2008.

Perdana, A \& Wildianti, D. (2019). Narasi Kampanye dan Media Sosial dalam Pemilu Presiden dan Wakil Presiden Tahun 2019. Jakarta: Bawaslu RI.

Nasional.tempo.co. (2019). Kronologi Penyerangan Jamaah Ahmadiyah Di Cikeusik. Online. Diakses dari https://nasional.tempo.co/read/311441/kronologi-penyerangan-jamaahahmadiyah-di-cikeusik

Nordholt, H, S., \& Klinken, G. (2007). Politik Lokal Di Indonesia. Jakarta: Yayasan Obor Indonesia dan KITLV Jakarta

Robinson, R., \& Hadiz, V. (2004). Reorganizing Power in Indonesia: The Politics of Oligarchy in Age of Markets. London: Routletge.

Romli, L. (2019). Political Identity and Challenges for Democracy Consolidation in Indonesia. Politik Indonesia: Indonesian Political Science Review, Vol 4, No 1. 
license

Santoso, Purwo. (2011). Proliferation of Local Governments in Indonesia: Indentity Politics within a Troubled Nation State. Journal of Power Conflict Democracy, Vol 3, No 1.

Sari, Endang (2016). Kebangkitan Politik Identitas Islam Pada Arena Pemilihan Gubernur Jakarta. Jurnal Ilmu Sosial dan Ilmu Politik, Vol 2, No 2.

Sarwono, J. (2006). Metode Penelitian Kuantitatif dan Kualitatif. Yogyakarta: Graha Ilmu.

Simandjuntak, D. (2018). Identity politics looms over Indonesia's presidential election. Retrieved November 13, 2018, from http://www.eastasiaforum.org/ 2018/1 1/10/identity-politicslooms-overindonesias-presidential-election/

Slater, D. (2004). Indonesian Accuntability Traps: Party Cartels and Presidential Power After Democracy Transition. Indonesia, No. 78 (Oktober).

The Wahid Institute. (2014). Laporan Tahunan Kebebasan Beragama/Berkeya-kinan dan Intoleransi. Jakarta: The Wahid Institue.

Tirto.id. (2017). 13 Hari Pembantaian Orang Cina di Jakarta. Online. Diakses dari https:/ / tirto.id/13-hari-pembantaian-orang-cina-di-jakarta-cx2Y

Tornquist, O. (2013). Assessing dynamics of democratisation: Transformative politics, new institutions, and the case of Indonesia. China: Palgrave Macmillan.

Tornquist, O \& Savirani, A. (2016). Reclaiming The State: Mengatasi Problem Demokrasi di Indonesia Pasca-Soeharto. Yogyakarta: PolGov.

Ubaid, A.,H \& Habibusabandi, H.,B. (2017). Political Polarization based on Religious Identities: Empirical Evidence from the 2017 Jakarta Gubernatorial Election. Jurnal Studi Pemerintahan, Vol 8, No 4.

Winters, J. (2014). Oligarchy and Democracy in Indonesia. In M. Ford, \& T. Pepinsky, Beyond Oligarchy: Wealth, Power, and Contemporary Indonesian Politics. New York: Cornell University Press.

Zuhro, R. S. (2019). Demokrasi Dan Pemilu Presiden 2019. Jurnal Penelitian Politik, Vol 16, No 1. 